\title{
Protein digestibility of a feed mixture in relation to the protein digestibility of the individual protein components
}

\author{
BY BJØRN O. EGGLM AND KONRAD D. CHRISTENSEN \\ Department of Physiology and Chemistry, Agricultural Research Laboratory, \\ Rolighedsvej 25, DK-1958 Copenhagen $V$, Denmark
}

(Received ${ }_{3}$ April 1973 - Accepted I9 September I973)

\begin{abstract}
r. Protein digestibility of two proteins was measured when these proteins were given together and separately to rats.

2. The influence of carbohydrates on protein utilization (true protein digestibility, biological value and net protein utilization) was also studied. Autoclaved potato starch was replaced by increasing amounts of glucose, sucrose, fructose and lactose respectively. Glucose, fructose and sucrose appeared to have no specific influence on protein utilization when given in increasing amounts and when compared with autoclaved potato starch. Higher concentrations of lactose, however, caused diarrhoea.

3. The true digestibility of the protein components in a mixture was directly related to the true digestibility of cach protein component, including proteins of low digestibility.
\end{abstract}

When using the direct method to determine protein digestibility each protein component is given separately. Feed mixtures, however, commonly contain two or more protein components, and the protein digestibility of the mixture might not always be an average of the protein digestibilities of the individual protein components. Furthermore, the response of an animal to a particular protein has been shown to depend upon the carbohydrate in the diet (Harper \& Katayama, I953; Register \& Peterson, I958; Guggenheim, Halevey \& Friedmann, I960; Dahlqvist \& Thomson, 1964). Complex carbohydrates are apparently more effective than single sugars in tests in which growth rate is one of the criteria (Hankes, Henderson, Brickson $\&$ Elvehjem, 1948; Harper \& Katayama, 1953; Chang, 1962). It has been suggested (Porter \& Rolls, 197I) that this effect is the result of slower passage of the digesta through the gut and consequently more complete liberation of amino acids. Other workers, however, have failed to demonstrate this effect (Spivey, Katayama, Yoshida \& Harper, I958; Chang, 1962).

Rapid movement of digesta through the intestine may impair the digestion of the dietary protein. Rogers \& Harper (1966) showed that the presence in the diet of carbohydrate affected the pattern of stomach emptying. However, Buraczewski, Porter, Rolls \& Zebrowska (197I) found that when different proteins were ingested with carbohydrate the behaviour of the meals was largely determined by the properties of the protein.

Porter \& Rolls ( $197 \mathrm{r}$ ) suggested that certain carbohydrates, particularly those that are very soluble but poorly absorbed, may reduce or delay the absorption of a feed by affecting stomach emptying and the absorption of amino acids. Buraczewski et al. (197I) showed that lactose tended to delay stomach emptying. Eggum (r973) showed that lactose ( $120 \mathrm{~g} / \mathrm{kg}$ diet), when given with different easily digestible protein sources, 
had a beneficial effect on protein retention in rats. Protein digestibility, however, was not affected by this lactose supplement. Eggum (1973) also showed that increasing amounts of cellulose powder or fat in the diet had no effect on either protein digestibility or protein retention.

Rolls, Porter \& Westgarth (1972) found that supplements of limiting amino acids did not affect the absorption of the proteins in rats, but the free amino acids were generally absorbed more rapidly than the protein-bound amino acids. Furthermore, Rolls et al. (1972) suggested that the rate of hydrolysis may be an important factor in protein absorption.

In our diets, feedstuffs that would give a high biological value of the protein were chosen. Very little attention was paid to the carbohydrate fraction or its possible effect on protein utilization.

Wiener, Yoshida \& Harper (1963) reported nitrogen-balance experiments which indicated that the type of dietary carbohydrate given to rats affected neither protein digestibility nor $\mathrm{N}$ retention. Similar results were obtained with minks in a comparison of maize starch and glucose (Glem Hansen, 1972). True protein digestibility (TD) and biological value (Bv) were unaffected by the carbohydrate source. In experiments with chickens, Bønsdorff Petersen ( 1972 ) compared the influence of glucose, sucrose, lactose and starch on protein digestibility and found that digestibility was independent of the carbohydrate source, although the higher concentration of lactose in the diet caused diarrhoea. Similar results were obtained by Thorbek \& Ludvigsen (I96I) in experiments with baby pigs. Bønsdorff Petersen (1972) suggested that in the lower part of the intestinal tract, higher concentrations of lactose or galactose might increase the osmotic pressure and give rise to increased water absorption. Under these conditions there may be an increase in microbial activity which might result in diarrhoea.

To illustrate the problems associated with the influence of carbohydrates on protein utilization, $\mathrm{N}$-balance experiments with rats were done. Autoclaved potato starch was replaced by increasing amounts of either glucose, sucrose, fructose or lactose in a diet with soya-bean meal supplemented with methionine as the protein source.

\section{EXPERIMENTAL}

\section{Animals and diets}

The experimental procedure has been described by Eggum (1973). Groups of five Wistar male rats weighing approximately $75 \mathrm{~g}$ were used. The preliminary period lasted for $4 \mathrm{~d}$ and the balance period for $5 \mathrm{~d}$. The rats were weighed at the beginning of the experiments and divided into groups of five such that the average weights of the groups differed by no more than $\pm 0.5 \mathrm{~g}$. Weighings were repeated at the end of the preliminary and balance periods; access to feed and water was restricted $3 \mathrm{~h}$ before weighing. Each animal received $150 \mathrm{mg} \mathrm{N}$ and $10 \mathrm{~g}$ dry matter daily throughout the preliminary and balance periods. The $\mathrm{N}$ content of the diet was adjusted by using a $\mathrm{N}$-free mixture consisting of autoclaved potato starch, sucrose, cellulose powder, soya-bean oil, minerals and vitamins (Table $\mathrm{I}$ ). This mixture has been used successfully for many years at the Oskar-Kellner Institute in Rostock. 
Table I. Composition (parts by weight) of the nitrogen-free mixture

$\begin{array}{lr}\text { Potato starch (autoclaved) } & 767 \\ \text { Sucrose } & 90 \\ \text { Cellulose powder } & 52 \\ \text { Soya-bean oil } & 52 \\ \text { Mineral mixture* } & 40 \\ \text { Vitamins† (mixed with autoclaved potato starch) } & 20\end{array}$

* To provide per $\mathrm{kg}$ diet: $\mathrm{CaCO}_{3} 2 \cdot 74 \mathrm{~g}$, calcium citrate $12.33 \mathrm{~g}, \mathrm{CaHPO}_{4} \cdot 2 \mathrm{H}_{2} \mathrm{O} 4.5 \mathrm{I} \mathrm{g}, \mathrm{K}_{2} \mathrm{HPO}_{4}$ $8.75 \mathrm{~g}, \mathrm{KCl}_{4} \cdot 99 \mathrm{~g}, \mathrm{NaCl}_{3} .08 \mathrm{~g}, \mathrm{MgSO}_{4} \mathrm{I}_{53} \mathrm{~g}, \mathrm{MgCO}_{3} \mathrm{I} \cdot 4 \mathrm{r} \mathrm{g}$, ammonium ferric citrate (brown, $20.5-22.5 \% \mathrm{Fe}) 0.6 \mathrm{I} \mathrm{g}, \mathrm{MnSO}_{4} \cdot \mathrm{H}_{2} \mathrm{O} 8.0 \mathrm{mg}, \mathrm{CuSO}_{4} \cdot 5 \mathrm{H}_{2} \mathrm{O}$ 3. I mg, KI I.6 mg, NaF $20.3 \mathrm{mg}$, $\mathrm{AINH}_{4}\left(\mathrm{SO}_{4}\right)_{2} \cdot \mathrm{I}_{2} \mathrm{H}_{2} \mathrm{O} 3 \cdot 6 \mathrm{mg}$.

† To provide per $\mathrm{kg}$ diet: retinol equivalent $\mathrm{r} \cdot 2 \mathrm{mg}$, cholecalciferol $7.5 \mu \mathrm{g}$, thiamin $0.8 \mathrm{mg}$, riboflavin $2 \mathrm{mg}$, nicotinamide $8 \mathrm{mg}$, pantothenic acid $2 \mathrm{mg}, \alpha$-tocopherol $0.4 \mathrm{mg}$, pyridoxine $0.2 \mathrm{mg}$.

The experimental diets were weighed out into plastic boxes with tightly fitting lids for each of the preliminary and balance periods. The feed was weighed each day from these boxes in four daily allowances in the preliminary period and five during the balance period. Any remaining feed was weighed and taken into consideration in the calculation of the experimental results.

\section{Expt I. Effect of carbohydrate source on protein utilization}

The test diets used contained $200 \mathrm{~g}$ soya-bean meal supplemented with $0.2 \mathrm{~g}$ methionine/kg dry matter and either $100 \mathrm{~g}$ or $200 \mathrm{~g}$ of glucose, sucrose, fructose or lactose $/ \mathrm{kg}$ diet replacing an equal weight of potato starch (Table 2). The effects of these changes on $\mathrm{TD}, \mathrm{BV}$ and net protein utilization (NPU) were recorded. If metabolic and endogenous $\mathrm{N}$ are included, as described by Mitchell (1924), the procedure provides a measure of absorbed protein and of the efficiency of the absorbed protein for the combined functions of growth and maintenance. Metabolic and endogenous $\mathrm{N}$ were determined by giving a diet containing $40 \mathrm{~g}$ freeze-dried egg protein $/ \mathrm{kg}$. Freeze-dried egg protein is completely utilized (Eggum, r973).

\section{Expt 2. Protein digestibility of mixtures of two proteins given separately and together}

The protein digestibility of a feed mixture might be considered as the average of the digestibilities of the protein components involved. To illustrate this aspect a number of experiments were carried out and TD of the proteins was recorded when feedstuffs were given separately or together.

\section{Analytical methods}

Freeze-dried samples of feedstuffs were analysed for dry matter and $\mathrm{N}$. $\mathrm{N}$ was determined in acidified samples of faeces and urine. The analyses were done according. to standard methods (Association of Official Agricultural Chemists, 1965).

\section{Statistical analyses}

Statistical analysis of the results was based on methods described by Snedecor (1956). 
Table 2. Expt x. Effects on protein utilization when rats were given a diet containing methionine-enriched soya-bean meal in which autoclaved potato starch (APO) was replaced as the carbohydrate source by increasing amounts of glucose, fructose, sucrose or lactose

(Mean values with their standard errors for groups of five rats)

\begin{tabular}{|c|c|c|c|c|c|c|}
\hline \multirow[b]{2}{*}{ Carbohydrate source } & \multicolumn{2}{|c|}{$\begin{array}{l}\text { True protein } \\
\text { digestibility } \\
\text { ratio }\end{array}$} & \multicolumn{2}{|c|}{$\begin{array}{l}\text { Biological } \\
\text { value }\end{array}$} & \multicolumn{2}{|c|}{$\begin{array}{l}\text { Net protein } \\
\text { utilization }\end{array}$} \\
\hline & Mean & SE & Mean & SE & Mean & $\mathrm{SE}$ \\
\hline $\mathrm{APO}$ & 0.90 & 0.01 & 0.88 & 0.01 & 0.80 & 0.01 \\
\hline $\begin{array}{r}\text { APO-glucose, } 80: 20 \\
60: 40\end{array}$ & $\begin{array}{l}0.92 \\
0.91\end{array}$ & $\begin{array}{l}0.01 \\
0.00\end{array}$ & $\begin{array}{l}0.89 \\
0.89\end{array}$ & $\begin{array}{l}0.00 \\
0.01\end{array}$ & $\begin{array}{l}0.82 \\
0.8 I\end{array}$ & $\begin{array}{l}0.00 \\
0.01\end{array}$ \\
\hline $\begin{array}{r}\text { APO-fructose, } 80: 20 \\
60: 40\end{array}$ & $\begin{array}{l}0.91 \\
0.92\end{array}$ & $\begin{array}{l}0.01 \\
0.01\end{array}$ & $\begin{array}{l}0.87 \\
0.87\end{array}$ & $\begin{array}{l}0.01 \\
0.01\end{array}$ & $\begin{array}{l}0.79 \\
0.80\end{array}$ & $\begin{array}{l}0.01 \\
0.01\end{array}$ \\
\hline $\begin{array}{r}\text { APO-sucrose, } 80: 20 \\
60: 40\end{array}$ & $\begin{array}{l}0.91 \\
0.90\end{array}$ & $\begin{array}{l}0.01 \\
0.01\end{array}$ & $\begin{array}{l}0.89 \\
0.89\end{array}$ & $\begin{array}{l}0.01 \\
0.01\end{array}$ & $\begin{array}{l}0.8 I \\
0.80\end{array}$ & $\begin{array}{l}0.01 \\
0.01\end{array}$ \\
\hline $\begin{array}{r}\text { APO-lactose, } 80: 20 \\
60: 40\end{array}$ & $\begin{array}{l}0.86 \\
0.71\end{array}$ & $\begin{array}{l}0.01 \\
0.02\end{array}$ & $\begin{array}{l}0.86 \\
0.83\end{array}$ & $\begin{array}{l}0.01 \\
0.02\end{array}$ & $\begin{array}{l}0.74 \\
0.59\end{array}$ & $\begin{array}{l}0.01 \\
0.02\end{array}$ \\
\hline
\end{tabular}

Table 3. Expt 2. True digestibility ratios (TD) for two proteins when included separately or together in diets given to rats

(Mean values for groups of five rats)

\begin{tabular}{|c|c|c|c|c|c|}
\hline Protein source & $\begin{array}{c}\text { Measured } \\
\text { TD }\end{array}$ & $\begin{array}{c}\text { Calculated } \\
\text { TD }\end{array}$ & Protein source & $\begin{array}{c}\text { Measured } \\
\text { TD }\end{array}$ & $\begin{array}{c}\text { Calculated } \\
\text { TD }\end{array}$ \\
\hline $\begin{array}{l}\text { Soya-bean meal } \\
\text { Barley } \\
\text { Soya-bean meal+barley }\end{array}$ & $\begin{array}{l}0.92 \\
0.80 \\
0.83\end{array}$ & 0.86 & $\begin{array}{l}\text { Skim-milk powder } \\
\text { Oats } \\
\text { Skim-milk powder + oats }\end{array}$ & $\begin{array}{l}0.91 \\
0.86 \\
0.88\end{array}$ & 0.88 \\
\hline $\begin{array}{l}\text { Fish meal } \\
\text { Barley } \\
\text { Fish meal + barley }\end{array}$ & $\begin{array}{l}0.91 \\
0.80 \\
0.86\end{array}$ & 0.86 & $\begin{array}{l}\text { Beans } \\
\text { Wheat } \\
\text { Beans + wheat }\end{array}$ & $\begin{array}{l}0.84 \\
0.90 \\
0.87\end{array}$ & 0.87 \\
\hline $\begin{array}{l}\text { Blood meal } \\
\text { Barley } \\
\text { Blood meal }+ \text { barley }\end{array}$ & $\begin{array}{l}1.00 \\
0.80 \\
0.90\end{array}$ & 0.90 & $\begin{array}{l}\text { Leaf protein } \\
\text { Barley } \\
\text { Leaf protein }+ \text { barley }\end{array}$ & $\begin{array}{l}0.93 \\
0.83 \\
0.86\end{array}$ & 0.88 \\
\hline $\begin{array}{l}\text { Meat and bone scraps } \\
\text { Barley } \\
\text { Meat and bone scraps }+ \\
\text { barley }\end{array}$ & $\begin{array}{l}0.88 \\
0.80 \\
0.84\end{array}$ & 0.84 & $\begin{array}{l}\text { Horse beans } \\
\text { Gluten } \\
\text { Horse beans + gluten }\end{array}$ & $\begin{array}{l}0.84 \\
r \cdot 01 \\
0.90\end{array}$ & 0.93 \\
\hline $\begin{array}{l}\text { Colza meal (rape seed) } \\
\text { Barley } \\
\text { Colza meal + barley }\end{array}$ & $\begin{array}{l}0.86 \\
0.80 \\
0.84\end{array}$ & 0.83 & $\begin{array}{l}\text { Peas } \\
\text { Barley } \\
\text { Peas + barley }\end{array}$ & $\begin{array}{l}0.85 \\
0.82 \\
0.83\end{array}$ & 0.84 \\
\hline $\begin{array}{l}\text { Herring meal } \\
\text { Barley } \\
\text { Herring meal + barley }\end{array}$ & $\begin{array}{l}0.87 \\
0.80 \\
0.83\end{array}$ & 0.84 & $\begin{array}{l}\text { Casein } \\
\text { Barley } \\
\text { Casein + barley }\end{array}$ & $\begin{array}{l}0.99 \\
0.86 \\
0.92\end{array}$ & 0.93 \\
\hline $\begin{array}{l}\text { Capelin meal (fish meal) } \\
\text { Barley } \\
\text { Capelin meal + barley }\end{array}$ & $\begin{array}{l}0.88 \\
0.80 \\
0.84\end{array}$ & 0.84 & $\begin{array}{l}\text { Grass meal } \\
\text { Casein } \\
\text { Grass meal + casein }\end{array}$ & $\begin{array}{l}0.6 \mathrm{I} \\
\mathrm{I} \cdot 00 \\
0.8 \mathrm{I}\end{array}$ & 0.80 \\
\hline $\begin{array}{l}\text { Soya-bean meal } \\
\text { Oats } \\
\text { Soya-bean meal + oats }\end{array}$ & $\begin{array}{l}0.88 \\
0.86 \\
0.90\end{array}$ & 0.87 & $\begin{array}{l}\text { Pellets (grass) } \\
\text { Casein } \\
\text { Pellets + casein }\end{array}$ & $\begin{array}{l}0.49 \\
\mathrm{I} \cdot 00 \\
0.74\end{array}$ & 0.74 \\
\hline
\end{tabular}




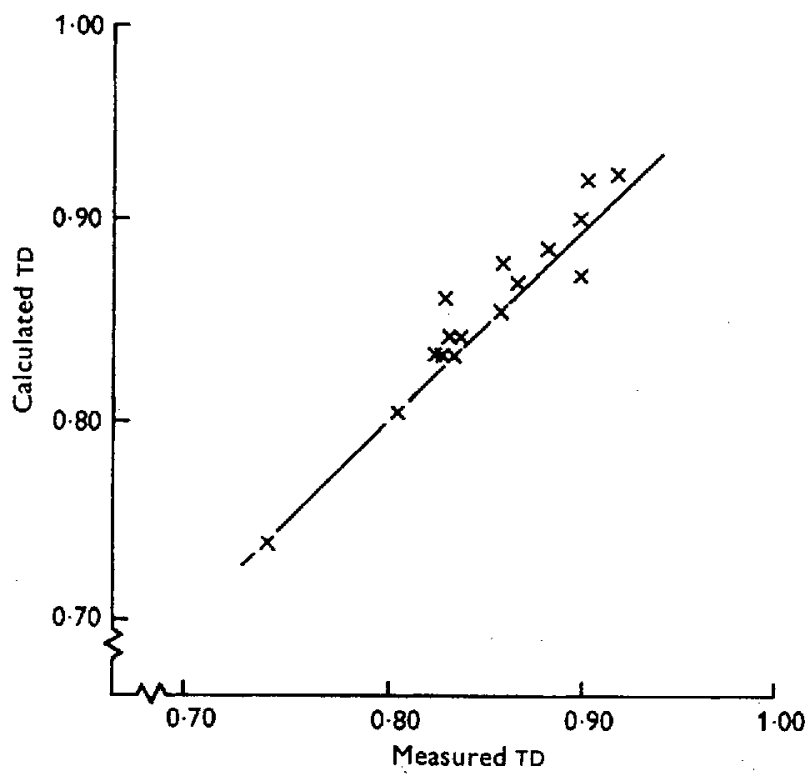

Fig. r. Measured true protein digestibility ratio (TD) plotted against TD calculated from the regression equation: calculated TD $=0.0084+0.99 \times$ measured TD.

\section{RESULTS}

Expt $\mathrm{x}$. The effect on protein utilization of replacing autoclaved potato starch in the diet by increasing amounts of glucose, fructose, sucrose or lactose are shown in Table 2. These results indicated that replacement of autoclaved potato starch by glucose, fructose or sucrose had no specific effect $(P>0.005)$ on protein utilization. Similar results were reported by Wiener et al. (1963). Lactose had a negative effect on both TD $(P<0.00 \mathrm{I})$ and $\mathrm{Bv}$. The effect on BV, however, was significant $(P<0.00 \mathrm{I})$ only when lactose was included at the highest concentration $(400 \mathrm{~g} / \mathrm{kg} \mathrm{diet})$. This effect may have been the result of diarrhoea, as the rats suffered from this disorder, particularly at the highest lactose concentration. However, Eggum (1973) found that rats given diets containing about $120 \mathrm{~g}$ lactose $/ \mathrm{kg}$ showed no signs of diarrhoea. This indicates an upper limit of tolerance for lactose.

Expt 2. Our results did not indicate that carbohydrates accompanying the proteins in the diet had any effect on protein digestibility. Porter \& Rolls (I97I), however, suggested that heat-damaged protein in a dict containing good-quality protein may reduce the digestibility of the latter. The different proteins chosen for our diets could have produced this effect, although Schiller (1956), using cod meal, peas, and cod meal + peas, and Nehring \& Bock ( 1962 ), using peas, soya-bean meal, and wheat, could provide no conclusive evidence of a reduction in digestibility.

Table 3 shows digestibility coefficients for different feedstuffs given either separately or together. In the mixtures of two protein sources each source contributed half the $\mathrm{N}$. The measured and calculated TD values were generally the same. The relationship between calculated and measured TD is shown in Fig. $\mathrm{I}$. The regression equation was: 
calculated TD $=0.0084+0.99 \times$ measured $\mathrm{TD}$. The following values were obtained: $r 0.96, s 0.014, s_{b} 0.08$, where $s$ is the deviation from regression and $s_{b}$ is the deviation of the regression coefficient. The regression coefficient differed significantly from zero $(P<0.001)$. The deviation from zero of the intercept of the regression was not significant.

\section{DISCUSSION}

The results confirm that both TD and $\mathrm{BV}$ of the protein are in general independent of the sources of carbohydrate in the diet (Wiener et al. 1963; Bønsdorff Petersen, I972; Glem Hansen, 1972). However, higher concentrations of lactose in the diet resulted in diarrhoea and therefore in a lower utilization. This has been demonstrated with baby pigs by Thorbek \& Ludvigsen (r96r) and with chickens by Bønsdorff Petersen (I972). We have shown that TD of a mixture of two protein sources is directly related to the TD values of the components determined separately. Eggum (I973) obtained similar results for the individual amino acid components.

We thank Alice Tommerup and Margit Jensen for tending the experimental animals and for careful analytical work and calculations.

\section{REFERENCES}

Association of Official Agricultural Chemists (1965). Official Methods of Analysis of the Association of Official Agricultural Chemists. Washington, DC: Association of Official Agricultural Chemists.

Buraczewski, S., Porter, J. W. G., Rolls, B. A. \& Zebrowska, T. (197I). Br. F. Nutr. 25, 299.

Bonsdorff Petersen, Chr. (1972). Ugeskr. agron. hort. 43, 872 .

Chang, Vet-Oy (1962). 7 . Nutr. 78, $2 \mathrm{x}$.

Dahlqvist, A. \& Thomson, D. L. (r964). Acta physiol. scand. 6r, 20.

Eggum, B. O. (1973). A study of certain factors infuencing protein utilization in rats and pigs. Thesis (Dr agric.), The Royal Veterinary and Agricultural University, Copenhagen.

Glem Hansen, N. (1972). Yearbook, Agricultural Research Laboratory, Copenhagen p. 23 r.

Guggenheim, K., Halevey, S. \& Friedmann, N. (I g60). Archs Biochem. Biophys. 9r, 6.

Hankes, L. V., Henderson, L. M., Brickson, W. L. \& Elvehjem, C. A. (1948). f. biol. Chem. r74, 873,

Harper, A. E. \& Katayama, M. C. (1953). \%. Nutr. 49, 261.

Mitchell, H. H. (1924). F. biol. Chem. 58, 873.

Nehring, K. \& Bock, H.-D. (1962). Arch. Tierernähr. 12, 53.

Porter, J. W. G. \& Rolls, B. A. (I971). Proc. Nutr. Soc. 30, 17.

Register, U. D. \& Peterson, E. W. (1958). F. Nutr. 64, 483 .

Rogers, Q. R. \& Harper, A. E. (1966). Wld Rev. Nutr. Diet. 6, 250.

Rolls, B. A., Porter, J. W. G. \& Westgarth, D. R. (1972). Br. F. Nutr. 28, 283.

Schiller, K. (1956). Arch. Tierernähr. 6, 92.

Snedecor, G. W. (1956). Statistical Methods 5 th ed. Ames, Iowa: Iowa State University Press.

Spivey, H. E., Katayama, M. C., Yoshida, M. \& Harper, A. E. (1958), Am. F. Physiol. r93, 479.

Thorbek, G. \& Ludvigsen, J. (196r). Proc. int. Congr. Anim. Husb. vill. Hamburg p. I 4.

Wiener, R. P., Yoshida, M. \& Harper, A. E. (1963). F. Nutr. 8o, 279. 